Original Paper http://ajol.info/index.php/ijbcs http://indexmedicus.afro.who.int

\title{
Bacteria associated with contamination of ready-to-eat (RTE) cooked rice in Lagos-Nigeria
}

\section{A.K.OGUNYEMI ${ }^{1 *}$, O.M. BURAIMOH ${ }^{2}$, N.O. ONUORAH ${ }^{1}$, S.M.C. EZEUGWU ${ }^{3}$, S.K. ODETUNDE ${ }^{1}$ and E.O. OLUMUYIWA ${ }^{4}$}

\author{
${ }^{I}$ Science Laboratory Department (Microbiology Unit), Lagos State Polytechnic, Ikorodu, Lagos, Nigeria. \\ ${ }^{2}$ Department of Microbiology, University of Lagos, Akoka, Lagos, Nigeria. \\ ${ }^{3}$ Nigerian Institute of Medical Research, Medical Bacteriology and Parasitology Laboratory (Diarrhea Unit), \\ Dept. of Microbiology, Yaba, Lagos-Nigeria. \\ ${ }^{4}$ Department of Biological Sciences, Bell University of Technology, Ota, Ogun- Nigeria. \\ * Corresponding author, E-mail: waleogunyemi2002@yahoo.com, Tel: +234 8034864513
}

\begin{abstract}
The bacteria associated with contamination of ready-to-eat (RTE) cooked rice in Lagos, Nigeria were studied using standard microbiological methods. The objective of this study was to investigate the distribution of pathogenic bacteria recovered from RTE cooked rice in Lagos, assess bacteria load in the contaminated RTE cooked rice and evaluate their microbial quality. The microbial load of the RTE cooked rice ranged from $1.5 \pm$ $0.29 \times 10^{4}-4.8 \pm 0.46 \times 10^{6} \mathrm{cfu} / \mathrm{g}$ for three markets. A further test revealed that the average bacteria counts at Ketu was significantly different from those at Yaba and Odogunyan. However it was found that counts at Yaba and Odogunyan were not significantly different. Based on the specification by the International Microbiological Standard limits for Foods (IMSF), the levels of contamination of the total samples that were above and below microbiological acceptable limit were $91.7 \%$ and $8.3 \%$ respectively. The predominant pathogenic bacteria associated with contamination of the RTE cooked rice samples were identified as Staphylococcus aureus, Brahamella sp, Enterobacter aerogenes and Salmonella typhi. Out of a total of 36 RTE cooked rice samples analyzed, Enterobacter aerogenes $36(100 \%)$ had the highest occurrence followed in descending order by Staphylococcus aureus 33 (91.7\%), Brahamella sp. 29 (80.6\%) and Salmonella sp. 25(69\%). The results indicated that most of the RTE cooked rice samples examined in this study did not meet bacteriological quality standards. These findings suggest that the presence of food pathogens in RTE rice hawked in our local markets may pose serious potential health risks to the consumers in the public.
\end{abstract}

(c) 2015 International Formulae Group. All rights reserved.

Keyword: Contamination, pathogenic, bacteria, ready-to-eat (RTE), cooked rice.

\section{INTRODUCTION}

Diarrhoeal disease remains one of the most important causes of morbidity and mortality in developing countries, especially in African countries (Kosek et al., 2003). Worldwide, acute diarrhoea constitutes a major cause of morbidity and mortality, especially among the very young, very old, and infirm. It is estimated that each year, U.S. adults experience 99 million episodes of acute diarrhoea or gastroenteritis, resulting in about 8 million physician visits and more than 
250,000 hospital admissions each year $(1.5 \%$ of adult hospitalizations). Most acute diarrhoea or gastroenteritis cases are caused by enteric infections. Diarrhoea is the third leading cause of death of under 5 after Malaria and upper respiratory infection. Diarrhoea kills an estimated 2.5 million people each year, with about $60-70 \%$ of them being children under five years of age (Cesar et al., 2000). The disease is responsible for over a quarter of the deaths of children in the world today (Yilgwan and Okolo, 2015). Most of these deaths occur in developing countries where an estimated $25 \%$ of under-five mortality is directly attributed to diarrhoea disease (Cesar et al., 2000; Yilgwan and Okolo, 2015). Ready-to-eat food (RTE) is a potential reservoir of pathogens that transmit diseases. Several studies have attributed diarrhoea and associated death to the consumption of contaminated RTE foods. An epidemiological link between RTE foods and diarrhoea has been reported (Mensah et al., 2000). Foodborne bacterial pathogens commonly detected in RTE foods are Bacillus cereus, Clostridium perfringens, Staphylococcus aureus and Salmonella spp. (Muleta and Ashnafi, 2001; Mankee et al., 2005; Ghosh et al., 2007; Christison et al., 2008; Manguiat and Fang, 2013; Vecdet Öz et al., 2014). Certain foods sold by street vendors, e.g. poultry, pork, beef, fish and rice, have been implicated in food poisoning outbreaks (Mensah et al., 2012). Several types of microorganisms have been known to affect the quality of food, thereby constituting health hazards when foods contaminated with these organisms are consumed. Evidence that people consumed RTE foods that are usually bought from food vendors is cooked rice. The level of contamination of RTE food is high in this environment and is a cause of concern because of high consumption of rice especially among children. Microbiological examination of foods especially ready-to-eat foods is very important since this helps to evaluate the safety of foods and provide measures to prevent foodborne disease outbreaks. According to Itoandon et al. (2011), the presence of mesophilic microorganisms in food is an indication that pathogenic microbes are likely to be present in such foods. A number of food items sold locally in Nigeria have been shown to be highly contaminated with Bacillus species (Oluwafemi and Simisaye, 2005; Yah et al., 2009; Okonko et al., 2009; Itoandon et al., 2011), Staphylococcus (Balaban and Rasooly, 2000; Oranusi et al., 2006a, 2006b) and other bacteria species (Ajao and Atere, 2009; Oranusi and Braide, 2012; Madueke et al., 2014). Information on factors that could compromise the quality of such RTE foods is important to inform good food preparation practices among the majority of Nigeria in order to avert food associated illness in the country. In this context, there is high consumption of RTE cooked rice in the country and despite evidence that most of them are prepared under unhygienic condition, their microbial quality is not known. The objective of this study was to investigate the distribution of pathogenic bacteria recovered from RTE cooked rice in Lagos, assess bacteria load in the contaminated RTE cooked rice and evaluate their microbial quality.

\section{MATERIALS AND METHODS \\ Study design, sampling and microbiological analyses \\ Cross sectional descriptive study on} RTE cooked rice with bacterial contaminants was carried out. RTE cooked rice from three markets in Lagos were processed for pathogenic microbial contaminants for their bacteria load estimation.

Lagos was purposefully selected due to the lack of microbiological data on RTE cooked rice. Three large markets in Lagos State were randomly selected and the markets were Yaba, Ketu and Odogunyan. The locations of the markets are shown in Figure 1. The vendors at the three markets where the RTE rice samples were sold were contacted and informed of the study. The samples were 
purchased and collected in sterile stomacher bags in icebox and transported immediately to the Medical Microbiology and Parasitology Laboratory of the Nigeria Institute of Medical Research, Yaba, Lagos, for analysis. A total of thirty-six samples were collected and analyzed. The rice samples were mashed aseptically in a sterile stomacher bag and 10.0 $\mathrm{g}$ of the mashed rice was suspended in $90 \mathrm{ml}$ of sterile normal diluent and serially diluted in same diluent. One milliliter $(1.0 \mathrm{ml})$ of appropriately diluted sample was pour plated in Nutrient Agar and the poured plates were incubated at $30{ }^{\circ} \mathrm{C}$ for $48 \mathrm{~h}$. The viable bacteria were enumerated and expressed as colony forming units (c.f.u) per gram sample. Representatives of the different colonies were selected according to their morphological characteristics, purified by successive subculturing on Nutrient Agar and identified phenotypically using standard methods (Buchannan and Gibbons, 1974).

\section{Identification of contaminating microorganisms \\ Bacterial isolates from growths on} Nutrient Agar medium were identified by the conventional taxonomic techniques as described by Buchanan and Gibbons (1974). Our identification was based on phenotypic characteristics only. The isolates could be further characterized using molecular method.

\section{Microbial counts and distribution}

Total pathogenic bacteria were enumerated in pour plates of Nutrient Agar (NA, Fluka) incubated at $30{ }^{\circ} \mathrm{C}$ for 48 h. All colonies appearing at the end of the incubation were counted and the result expressed as $\mathrm{cfu} / \mathrm{g}$ sample. The procedure used for enumeration of the viable counts were those described by Olutiola et al. (2000) and Nwachukwu and Akpata (2003).

\section{Statistical analysis}

The microbial quality of the RTE cooked rice samples from the three market locations was compared using one-way analysis of variance (ANOVA) (Mason et al., 2003) which assesses whether the means of groups are statistically different from each other. This analysis is appropriate whenever you are comparing groups, p-values less than 0.05 were considered significant.

\section{RESULTS}

Table 1 shows the population levels of pathogenic bacteria in the RTE rice samples collected from the three major markets. The population levels were $1.5 \pm 0.29 \times 10^{4}-4.8 \pm$ $0.46 \times 10^{6} \mathrm{cfu} / \mathrm{g}$. The level of contamination in the total samples was $96.7 \%$. From the same Table 1 above, Enterobacter aerogenes had the highest occurrence followed in descending order by Staphylococcus aureus, Brahmella sp. and Salmonella sp. Figure 2 compared the mean total bacteria counts obtained from each market and indicated those with the lowest and highest bacteria counts. The biochemical and morphological characteristics of the bacterial isolates from RTE cooked rice samples are shown in Tables 3 and 4. The bacteria identified were Staphylococcus aureus (N1), Brahamella sp (N2), Enterobacter aerogenes (N3) and Salmonella typhi (N4). The isolates identified in RTE cooked rice samples are clearly shown in Table 3. The overall comparison was significant ( $p$-value $=0.000<0.05$ ). While the average bacteria counts in Yaba market was significantly different from that of Ketu market, it was not significantly different from Odogunyan market. However, the average bacteria counts in Ketu market was significantly different from Yaba and Odogunyan markets (Table 2). 


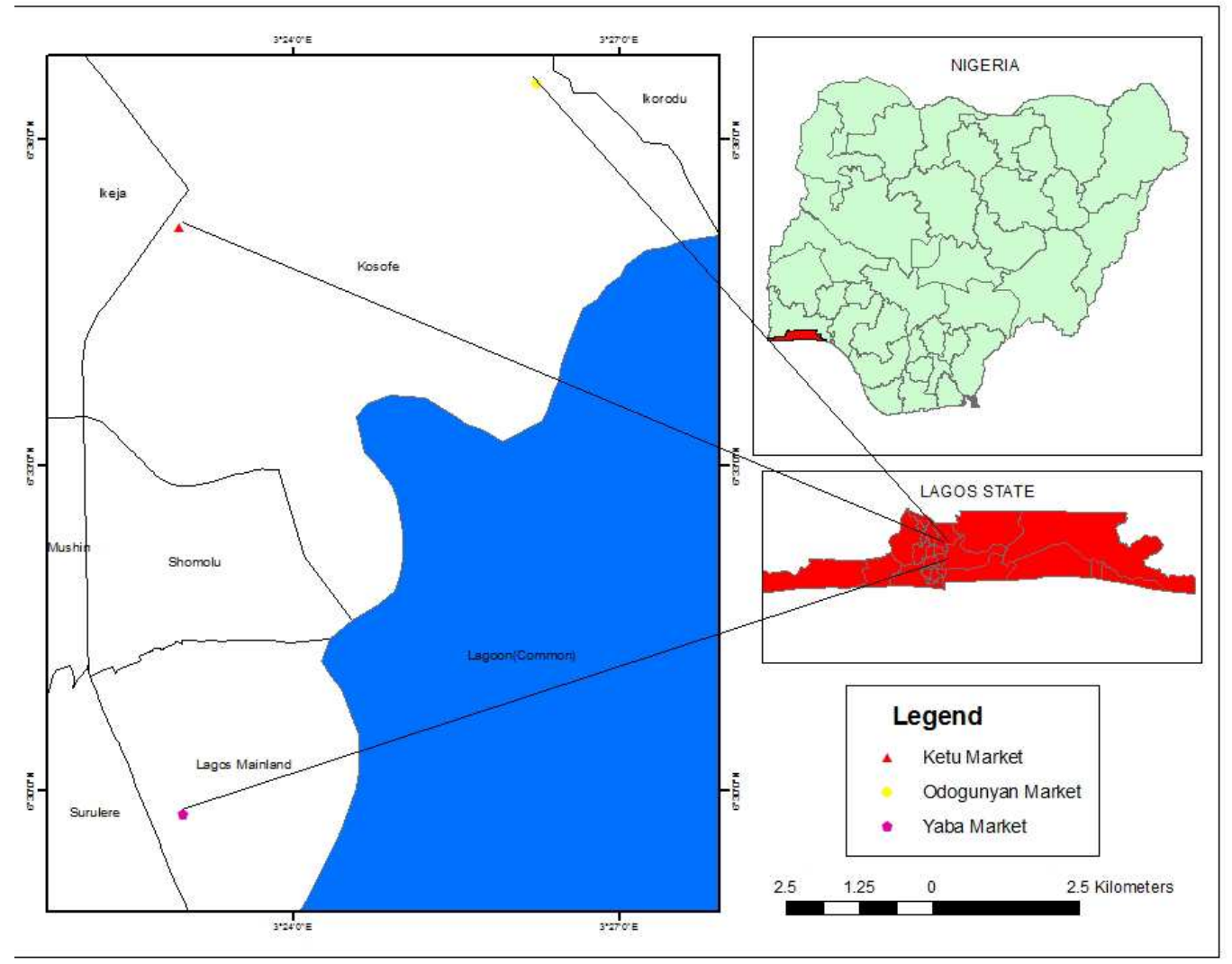

Figure 1: Map of the Lagos City showing markets and sampling points.

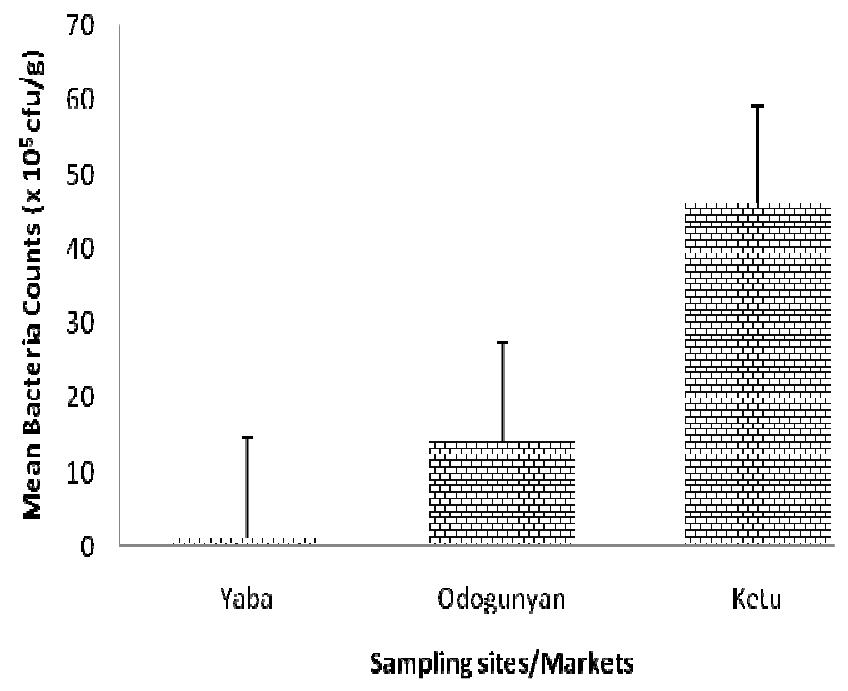

Figure 2: The mean bacteria counts of the cooked rice at the sampling sites/markets. 
A. OMOROGIUWA et al. / Int. J. Biol. Chem. Sci. 9(5): 2324-2333, 2015

Table 1: Total bacteria counts and their occurrence in RTE cooked rice samples.

\begin{tabular}{|c|c|c|c|c|c|c|c|c|}
\hline \multirow[t]{2}{*}{ Markets } & \multirow{2}{*}{$\begin{array}{l}\text { Cooked } \\
\text { rice } \\
\text { samples }\end{array}$} & \multirow{2}{*}{$\begin{array}{c}\text { Bacteria } \\
\text { counts cfu/g }\end{array}$} & \multirow{2}{*}{$\begin{array}{c}\text { Mean bacteria } \\
\text { counts } \\
\text { cfu/g }\end{array}$} & \multirow{2}{*}{$\begin{array}{c}\text { Levels of } \\
\text { contamination }\end{array}$} & \multicolumn{4}{|c|}{ Frequency of the Isolates } \\
\hline & & & & & $\begin{array}{c}\text { Staph. } \\
\text { aure. }\end{array}$ & $\begin{array}{c}\text { Brah. } \\
\text { spp }\end{array}$ & Entero. aerog. & Salmon. typh \\
\hline Yaba & $\mathrm{n}=12$ & $1.50 \pm 0.29 \times 10^{4}-10.00 \pm 1.16 \times 10^{5}$ & $4.1 \pm 0.0 \times 10^{5}$ & $75^{\mathrm{a}}$ & $9(75)$ & $9(75)$ & $12(100)$ & $9(75)$ \\
\hline Odogunyan & $\mathrm{n}=12$ & $1.00 \pm 0.15 \times 10^{5}-12.00 \pm 3.06 \times 10^{6}$ & $5.24 \pm 0.0 \times 10^{5}$ & 100 & $12(100)$ & $8(67)$ & $12(100)$ & $4(33)$ \\
\hline Ketu & $\mathrm{n}=12$ & $1.40 \pm 0.12 \times 10^{6}-4.80 \pm 0.46 \times 10^{6}$ & $3.60 \pm 0.0 \times 10^{6}$ & 100 & $12(100)$ & $12(100)$ & $12(100)$ & $12(100)$ \\
\hline & 36 & & & 96.7 & $33(91.7)$ & $29(80.6)$ & $36(100)$ & $25(69)$ \\
\hline
\end{tabular}

$\mathrm{a}=3 \mathrm{RTE}$ rice sample $<10^{5} \mathrm{cfu} / \mathrm{g}$ (Yaba market), Staph. aure $=$ Staphylococcus aureus, Brah. $\mathrm{sp}=$ Brahamella $\mathrm{sp}$, Entero. aerog=Enterobacter aerogenes, Salmon. typh $=$ Salmonella typhi., values in parenthesis ( ) are percentages.

Table 2: Multiple comparison of the average bacteria counts of the three markets.

\begin{tabular}{lcc}
\hline Market & Mean difference & p-value \\
\hline Ketu-Yaba & 2914583.333 & $0.000^{\mathrm{a}}$ \\
Ketu-Odogunyan & 2784166.667 & $0.000^{\mathrm{a}}$ \\
Yaba-Odogunyan & 130416.667 & $0.875^{\mathrm{b}}$ \\
\hline \multicolumn{2}{c}{${ }^{\mathrm{a}}$ mean difference is significantly at 0.05 level } & \\
${ }^{\mathrm{b}}$ mean difference is not significant at 0.005 level &
\end{tabular}


Table 3: Biochemical characteristics of bacteria isolates from RTE cooked rice samples.

\begin{tabular}{lcccc}
\hline Characteristics & \multicolumn{5}{c}{ Bacterial Isolates } \\
\cline { 2 - 5 } & N1 & N2 & N3 & N4 \\
\hline Catalase & + & + & - & + \\
Citrate & + & - & + & + \\
Oxidase & - & - & - & + \\
Coagulase & + & - & - & - \\
Indole test & + & + & - & - \\
Urease & - & - & + & - \\
Starch hydrolysis & - & - & - & - \\
Tributyrin hydrolysis & + & + & - & + \\
Glucose & + & + & + & + \\
Lactose & + & - & + & + \\
Sucrose & + & + & + & + \\
Mannitol & + & - & + & + \\
Identification & Staphylococcus & Brahamella sp & Enterobacter & Salmonella \\
& aureus & & aerogenes & typhi \\
\hline$+=$ positive,$-=$ negative & & & &
\end{tabular}

Table 4: Morphological features of the bacteria isolates in RTE rice samples.

\begin{tabular}{lcccc}
\hline Characteristics & N1 & N2 & N3 & N4 \\
\hline Gram reaction & + & + & - & - \\
Shape & Circular & Irregular & Spindle & Circular \\
Colour & Creamy & Creamy & Creamy & Whitish \\
Texture & Opaque & Translucent & Opaque & Translucent \\
Growth in Air & + & + & + & + \\
\hline
\end{tabular}

\section{DISCUSSION}

The microbial contamination of RTE cooked rice samples obtained from three major markets (Yaba, Ketu and Odogunyan) was studied. The data obtained in this study has demonstrated the activities of pathogenic bacteria associated with RTE foods and confirmed previous microbiological reports on other ready-to-eat street foods (Muleta and Ashanafi, 2001; Mensah et al., 2002; Bhaskar et al., 2004; Tambekar et al., 2008; Ajao and Atere, 2009; Oranusi and Braide, 2012; Nyenje et al., 2012; Vecdet Öz et al., 2014). The level of contamination of the total samples that was above acceptable limit was $91.7 \%$ while $8.3 \%$ was without contamination. In this study, the bacteria counts in the RTE rice sample ranged from $1.50 \pm 0.29 \times 10^{4}$ to $4.80 \pm 0.46 \times 10^{6} \mathrm{cfu} / \mathrm{g}$. Oranusi et al. (2013) also reported similar high bacterial population in some RTE foods including fried and jollof rice, coleslaw and moimoi which were in the range of $2.0 \times 10^{4}$ to $1.2 \times 10^{6} \mathrm{cfu} / \mathrm{g}$ for bacteria and $8.0 \times 10^{4}$ to $2.0 \times 10^{5} \mathrm{cfu} / \mathrm{g}$ for fungi. Olaoye et al. (2010) noted that relatively high temperature in tropical countries like Nigeria promotes rapid growth of pathogenic bacteria. Jalalpour (2012) examined the factors contributing to outbreaks of bacteria food poisoning caused by some notable food pathogens such as Salmonella spp., Staphylococcus perfringens, S. aureus, Shigella spp, Vibrio parahaemolyticus and Bacillus cereus. The 
high bacterial counts obtained in RTE cooked rice in this study may be attributed to several factors which include the initial contamination on the raw materials to the handling of the finished products. The utensils used in the preparation of cooked rice and sanitary condition of the processing environment especially air and dust-in-air may have contributed to increase in extent of contaminants. The contaminants used up the nutrient in the rice, grew and multiplied in their numbers. According to Hiu (2003), the total effects of such contaminating factors determines the quality of the rice, its probable shelf-life and the potential health risks specially if the contaminants are pathogenic in nature. The microorganisms found present in RTE cooked rice studied belong to the following genera, Staphylococcus, Brahamella, Enterobacter and Salmonella. In a similar study on RTE street foods in Accra, Ghana, Mensah et al. (2002) reported Citrobacter sp, Enterobacter sp, Staphylococcus aureus and Bacillus sp in Fufu samples. Also, Salmonella sp, Shigella sp, Lactic acid bacteria, Corynebacterium sp, Micrococcus sp, Klebisella sp and Enterobacter sp have been reported in other RTE street foods (Mensah et al., 2001; Mensah et al., 2002; Bhasker et al., 2004). Most of the isolates are common soil and water microorganisms. This is however not surprising since soil and water are included among the sources of microbial contaminants in food (Nguyen-the and Carlin, 2000; Hiu, 2003; Santamaria and Toranzos, 2003). According to these authors, soil is the single richest source of microorganisms, containing a wide variety and large numbers of microorganisms. Also, nearly all the microorganisms associated with food spoilage have their origin from the soil. The presence of enteric bacteria in the RTE cooked rice was however not unexpected, since the water used in preparing the rice by the sellers is most of the time untreated. This points to the fact that not everybody has access to potable water in Nigeria. Some of the bacteria isolated are normal flora of man, which are likely to have been introduced by food handlers through sneezing, talking and coughing. The presence of this group of organisms in the RTE cooked rice suggests that the rice were prepared under a low standard of hygiene. Some of the microorganisms (apart from being able to cause spoilage of the rice through their metabolic activities) are also pathogenic to the consumers. The results showed that $91.7 \%$ of the total samples were contaminated while $8.3 \%$ were below the contamination and also that the location does significantly influence the total bacteria plate counts $(\mathrm{p}<0.05)$. The recommended International microbiological standards limit of bacterial contaminant for total bacteria plate counts for foods is less than $10^{5} \mathrm{cfu} / \mathrm{g}$ of food (Rose and Osunnaiye, 2003; Oranusi et al., 2011; Okolie et al., 2012). The result presented heralded the fact that RTE cooked rice could be a source of diarrhoea and /or gastrointestinal disturbances (in both children and adults) if they exceed the acceptable limit. This is in agreement with the findings of other workers concerning street foods in countries with high ambient temperature condition (Muleta and Ashenafi, 2001; Manseh et al., 2002; Mulugeta and Bayeh, 2012).

\section{Conclusion}

Our findings revealed that ready-to-eat rice sold in these three large markets were contaminated with various pathogenic bacteria; this indicates inadequate processing and poor handling practices which can pose health risk to the consumers. However, good manufacturing practices (GMP) and hazard analysis critical control point (HACCP) application in the chain of food production and processing as well as health education to improve the knowledge of food vendors on food safety and hygienic practices should be encouraged. The findings indicated that is high level of contamination of RTE cooked rice in Lagos characterized by polymicrobial contaminants. We are of the view that if these preventive measures are not taken, outbreak of 
foodborne diseases is imminent since these foods are always bought as take-away foods by most of the consumers even at the close of their businesses late in the evenings. It is therefore necessary for Food Inspectors to monitor and prevent the sales of stale RTE foods in markets or other catering establishments.

\section{CONFLICT OF INTEREST}

The authors declare that there is no conflict of interest. The project was selffunded by the authors.

\section{AUTHORS' CONTRIBUTIONS}

The project was designed, supervised and participated by AKO. NOO was dutifully saddled with the task of data collection and participated; OMB co-supervised the work and participated while other co-authors participated in the work. It was self-funded by all the authors.

\section{ACKNOWLEDGEMENTS}

Our thanks go to the Nigerian Institute of Medical Research that provided space and equipment for us to carry out the project at the Medical Microbiology and Parasitology Laboratory, Department of Microbiology. Also, we would not forget to appreciate the Technologists in the Laboratory for their technical assistance rendered during the course of work.

\section{REFERENCES}

Ajao AT, Atere TG. 2009. Bacteriological Assessment and Hygienic Standard of Food Canteens in Kwara State Polytechnic, Ilorin, Nigeria. Afr. Scientist J., 3(10): 173-180.

Balaban N, Rasooly A. 2000. Staphylococcal enterotoxins. Int. J. Food Microbiol., 61: $1-10$

Bhaskar J, Usman M, Smitha S, Bhat GK. 2004. Bacteriological profile of street foods in Mangalore. Indian J. Medical Microbiol., 22: 97-197.
Buchanan RE, Gibbons NE 1974. Bergey's Manual of Determinative Bacteriology, ( $8^{\text {th }}$ Edn). The Williams \& Wilkins Co.: Baltimore.

Cesar GV, Bryce J, Fontaine O, Monasch R. 2000. Reducing deaths from diarrhoea through oral rehydration therapy. Bull World Health Org., 78: 1246-1255.

Christison CA, Lindsay D, von Holy A. 2008. Microbiological survey of ready-to-eat foods and associated preparation surfaces in retail delicatessens, Johannesburg, South Africa. Food Control., 19: 727-733.

Ghosh M, Wahi S, Kumar M, Ganguli. 2007. Prevalence of enterotoxigenic Staphylococcus aureus and Shigella species in some raw street vended Indian foods. Int. J. Environ. Health Res., 17: 151-156

Hiu YH. 2003. Plant Sanitation for Food Processing and Food Service ( $2^{\text {nd }}$ edn). CRC Press Taylor and Francis Group 6000 Broken sound Parkway NW Suite 300 : Boca Raton .

Itoandon EE, Olatope SOA, Orji FA, Morenike O, Shittu KA, Adebajo LO. 2011. Studies on production and activities of amylase, cellulase and pectinase enzymes of Bacillus and Aspergillus species from stale fast foods. Nig. J. Agriculture Food Environ., 7(4): 81-91.

Jalalpour S. 2012. Food borne diseases bacteria; frequency antibiotic resistance bacteria in Iranian foods. Afr. J. Microbiol. Res., 6(4):719-723.

Kosek M, Bern C, Guerrant RL. 2003. The magnitude of the global burden of diarrhoeal disease from studies published 1992-2000. Bull World Health Org., 81: 197-204.

Madueke SN, Awe S, Jonah A. 2014. Microbiological analysis of street foods along Lokoja-Abuja Express Way, Lokoja. American J. Resear. Commun., 2(1): 196-211.

Manguiat LS, Fang TJ. 2013. Microbiological 
quality of chicken- and pork-based street-vended foods from Taichung, Taiwan and Laguna, Philippines. Food Microbiol., 36(1): 57-62.

Mankee A, Ali S, Chin AL. 2005. Microbial quality of "doubles" sold in Trinidad. Food Microbiol., 22: 601-607.

Mason RL, Gunst RF, Ifess JL. 2003. Statistical Design and Analysis of Experiments. John Wiley and Sons: New Jersey.

Mensah P, Amar-Klemesu M, Hammond A, Haruna A. 2001. Bacterial contamination on lettuce, tomatoes, beef and goat meat from metropolitan Accra. Ghana Medical Journal, 35, 1-6

Mensah P, Mwamakamba L, Mohamed C, Nsue-Milang D. (2012).Public health and food safety in the WHO African region. Afr. J. Food Agriculture Nutr. Dev., 12(4):6317-6335.

Mensah P, Yeboah-manu, Owusu-Darko K, Ablordey A. 2002. Street food in Accra, Ghana: How safe are they? Bull. WHO, 80: 546-554. doi: $10.3923 / \mathrm{jm} .2010 .130 .136$

Muleta D, Ashnafi M. 2001.Salmonella, Shigella and growth potential of other food-borne pathogens in Ethiopian street vended foods. East Afr. Med. J., 78(11): $576-580$ http://dx.doi.org/10.4314/eamj.v78i11. 8946

Mulugeta K, Bayeh A. 2012. The sanitary conditions of food service establishments and food safety knowledge and practices of food handlers in Bahir Dar Town. Ethiop. J. Health Sci., 22(1):27-35.

Nguyen-the C, Carlin F. 2000. Fresh and Processed vegetables, In The Microbiological Safety and Quality of Foods. Lund BM, Baid-Parker TC, Gould GW (Eds). Aspen Publication: Gaithersburg; 620-684.

Nwachukwu SCU, Akpata TVI. 2003. Principles of Quantitative Microbiology ( $1^{\text {st }}$ Edn). University of
Lagos Press: Akoka, Lagos, Nigeria, 76.

Nyenje EM, Collins E, Odjadjare, Nicoline F, Tanih, Ezekiel G, Roland NN. 2012. Foodborne Pathogens Recovered From Ready-To-Eat Foods From Roadside Cafeterias and Retail Outlets In Alice, Eastern Cape Province, South Africa: Public Health Implications. Int. J. Environ. Res. Public Health. 9: 26082619.

Okolie NP, Omonigbehin E, Badru OA, Akande IS. 2012. Isolation of pathogenic bacteria from some foods sold at selected private schools in Akoka area of Yaba-Lagos, Nigeria. Afr. J. Food Sci., 6(3): 65-69.

Okonko IO, Adejoye OD, Ogun AA, Ogunjobi AA, Nkang AO, Adebayo BC. 2009. Hazards analysis critical control points (HACCP) and microbiology qualities of sea-foods as affected by handler's hygiene in Ibadan and Lagos, Nigeria. Afr. J. Food Sci., 3(2): 35-50.

Olaoye OA, Onilude AA, Idowu OA. 2010. Microbiological profile of goat meat inoculated with lactic acid bacteria cultures and stored at $30^{\circ} \mathrm{C}$ for 7 days. Food Bioprocess Technol. doi: 10.1007/s1 1947-010-0343-3.

Olutiola PO, Famurewa O, Sontagg HG. 2000. Introduction to Microbiology, $\left(2^{\text {nd }}\right.$ edn), Heidelberg: Nigeria; 267.

Oluwafemi F, Simisaye MT. 2005. Extent of Microbial Contamination of Sausages sold in two Nigerian cities. Afr. J. Biomed. Res., 9: 133 - 136

Oranusi S, Braide WA. 2012. Study of Microbial Safety of Ready-To-Eat Foods Vended On Highways: OnitshaOwerri, South East Nigeria. Int. Res. J. Microbiol., 3(2) 66-71.

Oranusi S, Galadima M, Umoh VJ. 2006a. Toxicity test and bacteriophage typing of $S$. aureus isolates from food contact surfaces and foods prepared by families in Zaria, Nigeria. Afr. J. Biotechnol., 
5(4) 362-365. DOI: 10.5897/AJB05.405

Oranusi S, Galadima M, Umoh VJ. 2006b. Phage typing and toxigenicity test of $S$. aureus strains from food contact surfaces and foods prepared in boarding schools in Zaria. Nigeria. Nig. J. Microbiol., 20(2): 1011-1017.

Oranusi S, Olorunfemi OJ. 2011. Microbiological safety evaluation of street vended ready-to-eat fruits sold in Ota, Ogun state, Nigeria. Int. J. Res. Biol. Sci., 1: 27-32.

Oranusi SU, Oguoma OI, Agusi E. 2013. Microbiological quality assessment of foods sold in student's cafeterias. Global Res. J. Microbiol., 3(1): 1 -7.

Rose EO, Osunnaiye E. 2003. Evaluation of microbial quality of foods in Bauchi. 27th Annual NIFST conference, Kano, Nigeria.

Santamaria J, Toranzos GA. 2003. Enteric pathogens and soil: a short review. Int. Microbiol., 6: 5-9.
Tambekar D, Jaiswal V, Dhanorkar D, Gulhane P, Dudhane M. 2008. Identification of microbiological hazards and safety of ready-to-eat food vended streets of Amravati City, In-dia. J. Appl. Biosci., 7: 195 - 201.

Vecdet Öz, Sukriye Karadayi, Hüseyin Çakan, Beytullah Karadayi and Filiz Ekim Çevik .2014. Assessment of microbiological quality of ready-to-eat foods in Istanbul, Turkey. J. Food Agriculture Environ., 12 (3\&4): 56-60

Yah SC, Nwinyi CO, Chinedu NS. 2009. Assessment of bacteriological quality of ready to eat food (Meat pie) in Benin City metropolis, Nigeria. Afr. J. Microbiol. Res., 3(6): 390-395

Yilgwan CS, Okolo SN. 2015. Prevalence of diarrhea disease and risk factors in Jos University Teaching Hospital, Nigeria. Ann. Afr. Med., 11: 217-21. 